\title{
You Say IFRS, I Say FASB...Let's Call The Whole Thing Off
}

Geoffrey Tickell, Indiana University of Pennsylvania, USA

Monsurur Rahman, Indiana University of Pennsylvania, USA

Romain Alexandre, Indiana University of Pennsylvania, USA

\begin{abstract}
This paper discusses the noticeable nervousness of many US-based financial statement issuers in adopting IFRS. For contextual purposes, the paper provides an overview of the FASB/IFRS convergence so far and its probable future. A detailed review of convergence in accounting standards is explained through the respective standards for "Pensions and Other PostEmployment Benefits". The paper concludes by suggesting that, while one set of global steps is a noble goal, it might not achieve the desired goal of comparability.
\end{abstract}

Keywords: Convergence; IASB; FASB; Accounting Standards; Pensions

\section{INTRODUCTION}

(8)

ince June of 1973, when the International Accounting Standards Committee (IASC) was founded, the accounting world has been striving toward one set of high-quality global financial accounting standards. Although slow to start, in the past 10 years, the pace has been gathering momentum. The primary thinking behind this ambitious move is that because the world's financial markets operate on a global scale, the financial information that these markets rely on needs to be of high-quality and comparable. High-quality requires the information to be relevant, reliable, and informative. Comparability requires the scorecard (e.g., Income Statements, Balance Sheets, Statement of Cash Flows) to be developed from the same set of rules (i.e., accounting standards). At the time of this writing, there are two sets of accounting standards being implemented across the globe - those issued by the Financial Accounting Standards Board (FASB) based in the US and International Accounting Standards Board (IASB) based in the UK. How and when the two sets of standards will become one is still to be decided; however, the most likely path is that of the IFRS becoming the global standards with individual country modifications.

This paper reviews the various paths to one set of global accounting standards and concludes with an analysis of the costs and benefits of this ambitious goal. In the process of doing this, the paper illustrates the convergence approach by outlining the similarities and differences with the accounting standards relating to "Pensions and Other Post-Employment Benefits" (POPEB). The paper concludes by posing the suggestion that, even if all nations adopt one set of accounting standards, comparability might not be achieved because many of the figures in financial statements are based on assumptions, estimations and interpretations that differ from company to company and country to country. Therefore, similar in principle to the George and Ira Gershwin song about "tomaytoes" and "tomahtoes", regional differences in dialects - or, in this case, generally accepted accounting principles - might cause the accounting world to say, "let's call the whole thing off".

\section{A BRIEF REVIEW OF THE STANDARD SETTING PROCESS}

Accounting standard setting was first implemented within each country with most countries establishing their own accounting setting body. For example, in 1939 the AICPA created the Committee on Accounting Procedure, being the first private sector organization to develop accounting standards. Other countries followed the UK in 1942 by establishing the Taxation and Financial Relations Committee, Australia in 1966 by forming the Australian Accounting Research Foundation, and New Zealand in 1966 when the New Zealand Institute of Chartered Accountants issued Statements of Standard Accounting Practice (Devonport and van Zij1 2012). 
The idea of the individual countries joining together to develop one set of global accounting standards found traction in 1973 when "The International Accounting Standards Committee" (IASC) was formed with an agreement from the accounting bodies of nine countries. In alphabetical order, they were Australia, Canada, France, Germany, Japan, Mexico, the Netherlands, the United Kingdom/Ireland, and the USA. In 1999, FASB outlined its vision for a single set of high quality accounting standards by publishing the International Accounting Standard Setting: A Vision for the Future (FASB 2012). In 2001, the IASC was replaced with the International Accounting Standards Board (IASB) which became the body responsible for developing and promoting the use of international accounting standards, known as International Financial Reporting Standards (IFRS).

In 2002, the IASB and FASB agreed to pursue a path of convergence (FASB, 2002). That is, they agreed to work toward making their existing standards fully compatible and that any new standards would be a coordinated effort between the two bodies. This agreement, known as the Norwalk Agreement, was endorsed by the SEC in April 2005 when its Chairman announced a "Roadmap to Convergence" (Nicolaisen, 2005). This proposed roadmap would eliminate, by 2009, the requirement for non-US based companies filing in the US to reconcile with US GAAP (known as the 20-F reconciliation). The Commission would decide by 2011 whether adoption of IFRS would be in the public interest and would benefit investors.

Toward the end of 2007, the FASB and the IASB completed their first major joint project and issued substantially converged standards on business combinations. In November 2008, the SEC published, for public comment, a proposed Roadmap to the possible use of IFRS by U.S. issuers beginning in 2014.

Many financial constituents in the US are expressing nervousness over the implementation of IFRS within the US market (Selling, 2008). Their concerns include: 1) the uncertain timetable for transition, 2) what components of US GAAP will be included in the global standards?, 3) whether IFRS will satisfy their financial reporting needs given that the FASB standards are far more detailed and prescriptive than the IFRS, 4) whether the benefits of adoption will outweigh the costs of preparing the statements, 5) will the new set of standards apply to all companies or will there be a distinction between listed companies and non-listed companies, or public and private companies?, and 6) will the financial statement preparers in their organization be ready for the move to one set of accounting standards?

For CEO's and CFO's, the new standards will apply to them when they sign-off on their financial statements. They need to understand the standards so as to implement them and, to some extent, be satisfied that the implemented standards allow their financial statements to present fairly the financial performance and financial position of their company. Further, the financial markets need to have confidence in the reported results of the companies.

In February 2010, the SEC reiterated that a single-set of high quality, globally accepted accounting standards would benefit US investors. In April 2011, the FASB and IASB reported on the progress of convergence and outlined three more standards for convergence; namely, financial instruments, revenue recognition, and leasing. In November 2011, the SEC released a Staff Paper entitled "Work Plan for the Consideration of Incorporating IFRS into the Financial Reporting System for US Issuers". In the Staff Paper (Panel 2011), the SEC explains that "The Commission has not yet made a decision as to whether and, if so, how, to incorporate IFRS into the financial reporting system for US issuers" (SEC, 2011, p. 1). The Staff Paper outlines four alternative approaches to the use of IFRS for US issuers: 1) full adoption of IFRS on a specified date without any endorsement mechanism, 2) full adoption of IFRS following staged transition over several years, 3) a voluntary adoption by US issuers, or 4) by incorporating IFRS into US GAAP (unofficially known as condorsement; i.e., convergence with endorsement). In July 2011, the SEC sought opinions on the condorsement approach. Opinions ranged from "just give us a date" to "let's forget the whole thing" (Dzinkowski, 2011).

The SEC paper outlines a different type of convergence than that undertaken by FASB-ISAB projects. The FASB-IASB approach, one might say, was to negotiate new standards. However, convergence, as explained in the Staff Paper, could also be seen as a movement by a country toward IFRS without any tangible IASB involvement. Under this convergence approach, countries do not adopt IFRS directly but rather maintain their local standards and merge them with their own standards over time. 
The Staff Paper mentions China as a country undertaking this approach. In contrast, the endorsement approach entails nations incorporating individual IFRS's into their local body of standards. However, countryspecific deviations are allowed. For example, this occurs when the IFRS are required to be translated into a nation's own local language, as some words or expressions do not translate accurately. This is the case for many countries within the European Union. Australia also adopts the endorsement approach with paragraphs being added to IFRS for the Australian-specific regulatory regime. These standards are referred to as A-IFRS. Therefore, the endorsement approach requires each country to maintain its own accounting standard setting body (Porter, 2005).

Presently, the SEC sees the US adopting a condorsement approach whereby the transition to IFRS would involve the IFRS being incorporated into US GAAP over a defined period of time, say five to seven years. At the end of this time, a US issuer would state that its financial statements are compliant with US GAAP and IFRS.

Table 1 contains an alphabetical list of the status of many countries and their adoption of IFRS or FASB standards. As can be seen from Table 1, almost all countries, except the US, have adopted IFRS. Furthermore, many countries (e.g., France) allow private companies to voluntary opt out of using IFRS.

Table 1: Adoption of IFRS by Selected Country

\begin{tabular}{|c|c|c|c|}
\hline Country & IFRS Adoption & $\begin{array}{c}\text { IFRS For Small And Medium Enterprises (SME)S } \\
\text { Required? }\end{array}$ & $\begin{array}{l}\text { Regulatory } \\
\text { Authorities }\end{array}$ \\
\hline Australia & $\begin{array}{l}\text { Required for all private } \\
\text { sector reporting entities and } \\
\text { as the basis for public sector } \\
\text { reporting since } 2005\end{array}$ & $\begin{array}{l}\text { The AASB decided not to adopt IFRS for Small and } \\
\text { Medium Enterprises (SME)s at this stage, but may } \\
\text { reconsider this decision at a future point in time. }\end{array}$ & $\begin{array}{l}\text { Australian } \\
\text { Accounting } \\
\text { Standards Board } \\
\text { (AASB) }\end{array}$ \\
\hline Austria & $\begin{array}{l}\text { Required for consolidated } \\
\text { financial statements }\end{array}$ & $\begin{array}{l}\text { IFRS for SMEs has not yet been adopted in the EU and is, } \\
\text { accordingly, not yet applicable for Austria. }\end{array}$ & $\begin{array}{l}\text { Austrian financial } \\
\text { reporting and } \\
\text { auditing } \\
\text { association }\end{array}$ \\
\hline Brazil & $\begin{array}{l}\text { Required for consolidated } \\
\text { financial statements of banks } \\
\text { and listed companies from } \\
31 \text { December } 2010 \text { and for } \\
\text { individual company accounts } \\
\text { progressively since January } \\
2008\end{array}$ & IFRS for SMEs are prohibited for Regulatory filings & $\begin{array}{l}\text { Comité de } \\
\text { Pronuncaimentos } \\
\text { Contábeis (CPC) } \\
\text { - Brazilian GAAP }\end{array}$ \\
\hline Canada & $\begin{array}{l}\text { Required from } 1 \text { January } \\
2011 \text { for all listed entities } \\
\text { and permitted for private } \\
\text { sector entities including not- } \\
\text { for-profit organizations. US } \\
\text { GAAP continues to be } \\
\text { acceptable for US listed } \\
\text { issuers. }\end{array}$ & $\begin{array}{l}\text { IFRS for SMEs are prohibited for statutory filings. Private } \\
\text { enterprises have the option of applying either IFRS or the } \\
\text { accounting standards for private enterprises (ASPE). }\end{array}$ & $\begin{array}{l}\text { Accounting } \\
\text { Standards Boards } \\
\text { of Canada }\end{array}$ \\
\hline China & $\begin{array}{l}\text { Substantially converged } \\
\text { national standards. However, } \\
\text { it is not a direct translation of } \\
\text { IFRS. }\end{array}$ & & $\begin{array}{l}\text { Ministry of } \\
\text { Finance, China } \\
\text { standard setter - } \\
\text { CAS: China } \\
\text { Accounting } \\
\text { Standards } \\
\end{array}$ \\
\hline $\begin{array}{l}\text { European } \\
\text { Union }\end{array}$ & $\begin{array}{l}\text { All member states of the EU } \\
\text { are required to use IFRSs as } \\
\text { adopted by the EU for listed } \\
\text { companies since } 2005\end{array}$ & & $\begin{array}{l}\text { Accounting } \\
\text { Regulatory } \\
\text { Committee } \\
\text { (ARC) }\end{array}$ \\
\hline France & $\begin{array}{l}\text { Required via EU adoption } \\
\text { and implementation process } \\
\text { since } 2005\end{array}$ & IFRS for SMEs are prohibited for statutory filings. & $\begin{array}{l}\text { Comité de la } \\
\text { Réglementation } \\
\text { Comptable }(\mathrm{CRC})\end{array}$ \\
\hline
\end{tabular}


Table 1 cont.

\begin{tabular}{|c|c|c|c|}
\hline Germany & $\begin{array}{l}\text { Required via EU adoption } \\
\text { and implementation process } \\
\text { since } 2005 \text { for consolidated } \\
\text { financial statements }\end{array}$ & IFRS for SMEs are prohibited for statutory filings & $\begin{array}{l}\text { Accounting } \\
\text { Standards } \\
\text { Committee of } \\
\text { Germany (HGB) }\end{array}$ \\
\hline Italy & $\begin{array}{l}\text { Required via EU adoption } \\
\text { and implementation process } \\
\text { since } 2005\end{array}$ & IFRS for SMEs are prohibited statutory filings. & $\begin{array}{l}\text { Organismo } \\
\text { Italiano di } \\
\text { Contabilità }\end{array}$ \\
\hline Japan & $\begin{array}{l}\text { Permitted from } 2010 \text { for a } \\
\text { number of international } \\
\text { companies; decision about } \\
\text { mandatory adoption by } 2016 \\
\text { expected around } 2012 \text {. }\end{array}$ & $\begin{array}{l}\text { In June 2011, the Accounting Standards Board of Japan and } \\
\text { the IASB announced "The Tokyo Agreement" which } \\
\text { targeted June } 2011 \text { to reduce differences in specific items }\end{array}$ & $\begin{array}{l}\text { Accounting } \\
\text { Standards Board } \\
\text { of Japan (ASBJ) }\end{array}$ \\
\hline Mexico & $\begin{array}{l}\text { Mexico will require adoption } \\
\text { of IFRS for all listed entities } \\
\text { starting in } 2012 .\end{array}$ & $\begin{array}{l}\text { Currently there is no plan requiring private companies to } \\
\text { adopt IFRS. }\end{array}$ & $\begin{array}{l}\text { Mexican Board } \\
\text { for Research and } \\
\text { Development of } \\
\text { Financial } \\
\text { Reporting } \\
\text { Standards }\end{array}$ \\
\hline $\begin{array}{l}\text { New } \\
\text { Zealand }\end{array}$ & $\begin{array}{l}\text { IFRS required for } \\
\text { consolidated and } \\
\text { standalone/separate financial } \\
\text { statements }\end{array}$ & $\begin{array}{l}\text { NZ IFRS is required for some companies and IFRS for } \\
\text { SMEs are prohibited for statutory filings }\end{array}$ & $\begin{array}{l}\text { External } \\
\text { Reporting Board } \\
\text { (XRB) }\end{array}$ \\
\hline Norway & $\begin{array}{l}\text { Required for consolidated } \\
\text { financial statements and for } \\
\text { some companies in the } \\
\text { financial industry. From } \\
2011 \text { required for entities } \\
\text { which don't have any } \\
\text { subsidiaries. Permitted for } \\
\text { separate financial statements. }\end{array}$ & $\begin{array}{l}\text { IFRS are permitted for consolidated and standalone/separate } \\
\text { financial statements. IFRS for SMEs is prohibited statutory } \\
\text { filings. There are some limitations in the financial industry. }\end{array}$ & $\begin{array}{l}\text { The Norwegian } \\
\text { Accounting } \\
\text { Standards Board }\end{array}$ \\
\hline $\begin{array}{l}\text { United } \\
\text { Arab } \\
\text { Emirates }\end{array}$ & $\begin{array}{l}\text { Required for consolidated } \\
\text { and standalone/separate } \\
\text { financial statements. }\end{array}$ & IFRS for SME are not in use as yet. & \\
\hline Russia & $\begin{array}{l}\text { Consolidated financial } \\
\text { statements under IFRS will } \\
\text { be required for public } \\
\text { interest entities (PIEs). The } \\
\text { date of transition to IFRSs } \\
\text { will be } 1 \text { January } 2011 \text {, with } \\
\text { the first full set of IFRS } \\
\text { financial statements covering } \\
2012 \text { calendar year }\end{array}$ & & $\begin{array}{l}\text { National Council } \\
\text { on Financial } \\
\text { Statements } \\
\text { Standards } \\
\text { (NSFO) }\end{array}$ \\
\hline $\begin{array}{l}\text { United } \\
\text { Kingdom }\end{array}$ & $\begin{array}{l}\text { Required via EU adoption } \\
\text { and implementation process } \\
\text { since } 2005\end{array}$ & IFRS for SME's and FRSSE & UK ASB \\
\hline $\begin{array}{l}\text { United } \\
\text { States }\end{array}$ & $\begin{array}{l}\text { Allowed for foreign issuers } \\
\text { in the US since } 2007 \text {. The } \\
\text { SEC also issued a work plan } \\
\text { with six areas that need to be } \\
\text { addressed to enable the SEC } \\
\text { to make a decision in } 2011 \\
\text { on whether to incorporate } \\
\text { IFRS in the US public } \\
\text { reporting structure possibly } \\
\text { by } 2015 \text { or } 2016 \text {. }\end{array}$ & & $\begin{array}{l}\text { Financial } \\
\text { Accounting } \\
\text { Standards Board } \\
\text { (FASB) }\end{array}$ \\
\hline
\end{tabular}




\section{PENSIONS AND OTHER POST-EMPLOYMENT BENEFITS}

This paper uses the standards issued by IASB and the FASB, respectively, that relate to "Pensions and Other Post-Employment Benefits" (POPEB) as an illustration of standards that were developed from a joint IASBFASB project and yet still retain enough differences to not enable adequate comparability.

The principle source of guidance for the IFRS standard on POPEB comes from IAS 19. For US GAAP, the guidance is spread across five standards - FASB ASC Topics 712, 715, 960, 962, and 965. For the most part, there has been significant convergence between IFRS and US GAAP in the development of these standards; however, differences remain.

The accounting treatment for POPEB is complex. The aim of accounting for POPEB is to measure the costs associated with providing retirement benefits (i.e., paid sometime in the future) during the employee's period of service (i.e., the current accounting year). Many assumptions and estimations are required and these variants can have a significant impact on the company's reporting of their financial performance and financial position. This is especially the case with Defined Benefit (DB) Pension Plans. Here, the employer bears the risk that the plan assets will be sufficient to meet the future needs of their retired employees. If the amount of assets in the DB Plan exceeds the present value of the estimated liability, the plan is said to be overfunded. If the opposite is the situation, then the plan is underfunded. Despite being underfunded, the company is still required to make good those pension payments when they fall due.

Actuarial assumptions are required to determine the present value of obligations for benefits vested by its current and former employees. These assumptions are used to determine the expense in the current year. These assumptions include employee turnover, life-expectancy rates, mortality rates, retirement ages, and compensation increases. IAS 19 requires companies to report a defined benefit liability on their balance sheet equal to the net total of the present value of the DB obligation, plus any actuarial gains (or less any losses), minus any past service costs, minus the fair value of the plan assets. Smoothing is allowed. SFAS 158 (which took effect in 2006) requires companies to report on their balance sheet the difference between the defined benefit obligation and the fair value of the plan assets. If the plan is overfunded, then an asset is reported, whereas a liability is reported for an underfunded fund.

Under IFRS, past service costs are recognized immediately in the period when the change occurs to the extent that the benefits are vested or amortized on a straight-line basis over the average period until the benefits become vested and reported as an expense on the income statement. Unamortized past service costs are disclosed in the footnotes and used to calculate the funded status of the plan, and the resulting pension liability or asset is reported in the balance sheet (Robinson, van Greuning et al., 2009).

Under US GAAP, prior service costs are reported in other comprehensive income in the period in which the change occurs. In subsequent periods, these costs are amortized over the average service lives of the employees and reported as a component of pension expense. Unamortized past service costs are reported in accumulated other comprehensive income and are not included in calculating the funded status of the plan (Robinson, van Greuning, et al., 2009).

Further, IFRS do not require companies to present the various components of pension expense as a net amount on the income statement but rather they may disclose portions of the pension expense within different line items on the income statement. US GAAP, however, does require all components of net periodic pension expense to be aggregated and presented as a net amount within the same line on the income statement (Robinson, van Greuning et al., 2009).

Several aspects of the accounting for POPEB can affect comparative financial statement analysis. For example, differences in key assumptions (e.g., discount rates) can affect comparisons. Differences between US GAAP and IFRS in how the fund is reported in the financial statements can also affect comparisons. Under US GAAP, all of the components of pension expense are reported within a single line item that is treated as an operating expense whereas with IFRS, the components of pension expense can be included in various line items. 
A company's balance sheet reports the net funded position of a company's POPEB. Under IFRS, the present value of the defined benefit obligation may be adjusted for a number of deferred items. In addition, there is a limitation on the amount of a pension asset that can be reported. Thus, the gross benefit obligation might only be shown in the footnotes. Under US GAAP, companies now report the entire net pension obligation on the balance sheet without any adjustments and there are no limitations on the amount that can be shown.

For comparative purposes, financial analysts will know that if the gross benefit obligation is large relative to the total assets, shareholders' equity, and net income, then a small change in the pension liability can have a significant financial effect on the company. These small changes might result from tweaking the discount rates, employee turnover, length of service, rate of increase in compensation levels, and/or life-expectancy. To a large extent, management has discretion over these inputs. Furthermore, differences in a country's social system, laws, and regulations can result in differences in a company's pension plans (Robinson, van Greuning et al., 2009).

\section{CONCLUSION}

The US Securities and Exchange Commission (SEC) will decide when and how US financial statement issuers will need to comply with IFRS. The Commission is still exploring a variety of options. The decision for adoption continues to be deferred to sometime in the future. Debate is still strong as to how IFRS should be adopted within the US. In 2011, the American Institute of Certified Public Accountants (AICPA) issued a comment letter to the US Securities and Exchange Commission (SEC) advocating that US public companies be given the option to adopt IFRS. That is, to let the market decide (Parks 2011). Reasons for adopting IFRS are well known and well accepted (i.e., for comparability). Reasons for not adopting IFRS are less clear but include: 1) the cost of conversion for no real measurable benefit, 2) IFRS are principled-based and provide less guidance than FASBs prescriptive and more detailed standards, 3) IFRS are not compatible with US-style corporate governance, and 4) the loss of US influence over standard-setting and concern over the independence of IASB (Selling, 2008). Despite these concerns, the process of IFRS-FASB convergence continues. In November 2011, the IASB and the FASB issued, for public comment, a revised draft of the Revenue Recognition standard (FASB, 2011).

Comparability, and as a consequence, more informed decision-making is the main objective of having one set of global accounting standards. However, as this paper explains, by comparing the two sets of standards related to POPEB, even if all listed companies around the world adopt the same set of standards (e.g., IFRS), there is still sufficient leeway, with respect to estimations and assumptions, for the financial statements to not be comparable. Therefore, this noble objective of one set of high-quality global accounting standards is unlikely to achieve the desired objective of comparability. Given this result, and using a cost-benefit analysis, it might be best to call the whole thing off.

\section{AUTHOR INFORMATION}

Geoffrey Tickell, Ph.D, CPA, is a Professor of Accounting at Indiana University of Pennsylvania. His doctorate is from Monash University, Australia. He has taught accounting courses in higher education for over 20 years. His research interests include accounting education and international accounting. E-mail: imgn@iup.edu (Corresponding author)

Monsurur Rahman is a Professor of Accounting at Indiana University of Pennsylvania. He received his doctorate from Southern Illinois University - Carbondale. He is a CPA and CMA. His research has been published in The National Accounting Journal, Southwest Business and Economics Journal, and Journal of Accounting and Finance Research, and many national regional conference proceedings. His research interests are in the area of Financial and Managerial Accounting. E-mail: mrahman@iup.edu

Romain Alexandre is currently working as a Financial Analyst in the private sector. He has a Masters of Finance from ICN Business School, France, and an MBA from Indiana University of Pennsylvania. His work experience and interests are in the area of financial analysis. E-mail: romain.alexandre@myicn.fr 


\section{REFERENCES}

1. $\quad$ AICPA. (2008). "International Financial Reporting Standard for Small-and Medium-Sized Entities." Retrieved 2/4/2011, 2011, from http://www.ifrs.com/overview/IFRS_SMES/IFRS_SMES_FAQ.html\#q2

2. Devonport, B. and T. van Zijl (2012). Standard Setting for Financial Reporting in the New Zealand Public Sector.

3. Dzinkowski, R. (2011). Skirmish Over Standards. In the Black. (CPA Australia), November 2011: 53-55.

4. FASB (2002). Memorandum of Understanding: The Norwalk Agreement, The Financial Accounting Standards Board.

5. FASB. (2011). "News Release 11/14/11: IASB and FASB publish revised proposal for revenue recognition." Retrieved 2/14/2012, from http://www.fasb.org/cs/ContentServer?c=FASBContent_C\&pagename=FASB/FASBContent_C/NewsPage $\underline{\text { \&cid}=1176159289959}$

6. $\quad$ FASB. (2012). "International Convergence of Accounting Standards - A Brief History." Retrieved $2 / 14 / 2012$, from http://www.fasb.org/cs/ContentServer?c=Page\&pagename=FASB $\% 2 F P a g e \% 2 F S e c t i o n P a g e \& c i d=117615$ $\underline{6304264}$

7. Nicolaisen, D. (2005). "A securities regulator looks at convergence " Northwestern Journal of International Law and Business 3(Spring): 661-686.

8. Panel, B.-R. (2011). Report to the Board of Trustees of the Financial Accounting Foundation, Blue-Ribbon Panel on Standard Setting for Private Companies.

9. Parks, P. (2011). Let the Market Place Decide IFRS Adoption. AICPA Insights, AICPA.

10. Porter, B. (2005). A-IFRS vs IFRS. Sydney, Deloitte.

11. PWC (2009). IFRS for SMEs. How does this affect US companies? Retrieved on 2/12/2012. http://www.pwc.com/us/en/issues/ifrs-reporting/assets/ifrs_for_smes_us.pdf

12. Robinson, T. R., J. H. van Greuning, et al. (2009). International Financial Statement Analysis, CFA Institute.

13. Selling, T. (2008). "Top Ten Reasons Why U.S. Adoption of IFRS is a Terrible Idea." The Accounting Onion Retrieved 2/13/2012, from http://accountingonion.typepad.com/theaccountingonion/2008/09/topten-reasons.html 
NOTES 